\title{
Coral Fish Ecology Syngnathidae as Ecotourism Supporting Power in Blue Lagoon Coastal Waters Karangasem, Bali
}

\author{
Suprabadevi Ayumayasari Saraswati", Dewa Ayu Angga Pebriani, Kolis Pratama \\ Study Program of Aquatic Resource Management, Faculty of Marine Science and Fisheries, Udayana University \\ *Corresponding author: suprabadevi@yahoo.com
}

\begin{abstract}
The Syngnathidae reef fish belongs to the vulnerable category of CITES due to the decrease in its original habitat. This is due to the high activity of predatory and utilization as raw material of traditional medicine. This study aims to study the ecological conditions including the distribution and abundance of reef fish Syngnathidae in the waters of the Blue Lagoon Karangasem waters and study the physical condition of its aquatic chemistry. This research was conducted from August to October 2017. The determination of research station was done based on Purposive sampling methods. For data retrieval of the Syngnathidae reef fish using square squares method with size $10 \times 10 \mathrm{~m}$ in each sampling location. The result of this research is the emergence of species of reef fish Syngnathidae ranged from 1-4 individual at each location of observation. The results show that the ecological condition of the Syngnathidae reef fish in the Blue Lagoon coastal waters is of concern, this refers to the distribution and abundance of the limited reef fish Syngnathidae in its distribution. On the other hand, analysis of physical chemistry data shows that the condition of Blue Lagoon coastal waters tends to be stable. Measurement of water physics-chemical parameters obtained result of temperature measurement range $28-29^{\circ} \mathrm{C}$, salinity $27-29 \mathrm{ppt}, \mathrm{pH} 7.08-7,89$ and $\mathrm{DO}$ 7-7,75 mg/l. The result of physicochemical parameter measurement is related to the quality standard of Kep.Men.LH No.51 about the quality of the waters for marine biota was good for the existence of Syngnathidae reef fish. In general, the aquatic chemical physics conditions have a significant influence on the emergence of reef fish Syngnathidae found in stations 1 and III but not found in station II located in the middle of the waters between stations I and III.
\end{abstract}

Keyword: Ekologi, Syngnathidae, distribution, physicochemical, Blue Lagoon

\section{INTRODUCTION}

Blue Lagoon beach is located in Padangbai village, Manggis district, Karangasem regency of Bali. Ecologically this area is one of the ancient lava flows of Mount Merapi Agung, this refers to the arrangement of lava rocks that surround the area. The ecosystem of the region consists of waters and forests based on karst upland stones with the dominance of vegetation in tree growth form along the coastline.

The reef fish community within a coral reef ecosystem is affected by the presence of live corals. Dead coral causes a marked decrease in the number of fish species and individuals associated with reefs [1]. Live reef fish associate with reefs in their preferred habitat, that is areas that provide plenty of food. Coral fish use coral reef forms to protect themselves from predatory attacks [2].

Coral fish are generally relatively sedentary. One of the reef fish communities living on the Blue Lagoon coast is Syngnathidae. Based on this it is necessary to monitor the reef fish family Syngnathidae, which in this case take samples pipefish and sea horses to study the current conditions that include the distribution and abundance of species in the waters of Blue Lagoon Karangasem.

The purpose of this study is to determine the ecological conditions include the distribution and abundance of reef fish Syngnathidae in Blue Lagoon Karangasem Bali Beach Waters.

The benefits of this study are expected to provide information about the ecological condition of the reef fish habitat Syngnathidae in the Blue Lagoon Coast waters of Karangasem, Bali. As well as the basic conservation policy making area Blue Lagoon Karangasem Bali. And as a rationale for implementing ecotourism management area. at Blue Lagoon Beach Waters, Bali.

\section{RESEARCH METHODS}

The method used in this research is descriptive method. The research variables observed in this study were to calculate abundance, density, and water quality analysis on the ecology of the Syngnathidae habitat.

The location of the data was taken in the Blue Lagoon waters of Karangasem, Bali (Fig. 1). Data taken based on ground check results in the field. The study was conducted from August to October 2017. 


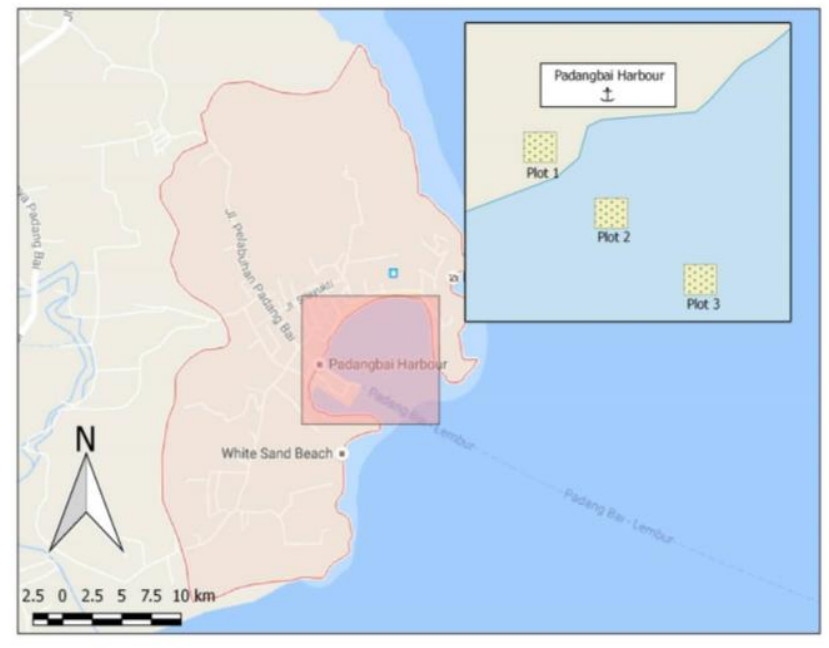

Fig. 1. Reasearch Located.

Sampling is done by quadratic sampling method that used with size $100 \mathrm{~m}^{2}(10 \mathrm{~m} \times 10 \mathrm{~m})$ in order to get chance of finding coral fish because of unbalanced reef fish distribution. The number of sampling squares in each sampling location is 3 quadrants representing the coral reef habitat of $1000 \mathrm{~m}^{2}$ where coral reefs are one of the most populated habitats for the reef fish Syngnathidae. Of the three quadrants a fruit is on the edge of the beach, one fruit is in the middle and one more is farthest away from the beach. On population estimation by using fishing gear. The time interval of the force should be consistent. Water quality measurements were conducted directly at the study sites with the parameters tested were $\mathrm{pH}$, DO (Dissolved Oxygen), temperature, and salinity.

The sampling data is then calculated using the Catch formula per Unit of Effort to predict the abundance and density. Abundance and density analyzes were calculated using formulas referring to [3], [4], [5], [6] as follows:

\section{Abundance}

$$
\mathrm{KL}=\mathrm{Ji} / \mathrm{Ja}
$$

Where :

KL : Abundance

$\mathrm{Ji}$ : Number of individual catches

$\mathrm{Ja} \quad$ : Number of catch

Density

$$
\mathrm{Kp}=\mathrm{Ji} /(\mathrm{Lp} \times \mathrm{Jp})
$$

Where :

$\mathrm{Kp}$ : Density

$\mathrm{Ji} \quad$ : Number of individual catches

Lp : Extensive plot/sea horse sampling station

Jp : Number of plots/stations

\section{RESULTS AND DISCUSSION}

The observation of the percentage distribution of sea horse species found in Blue Lagoon Karangaem Beach
Waters, Bali at the time of study every month from August to October 2017 can be seen in Fig 2.

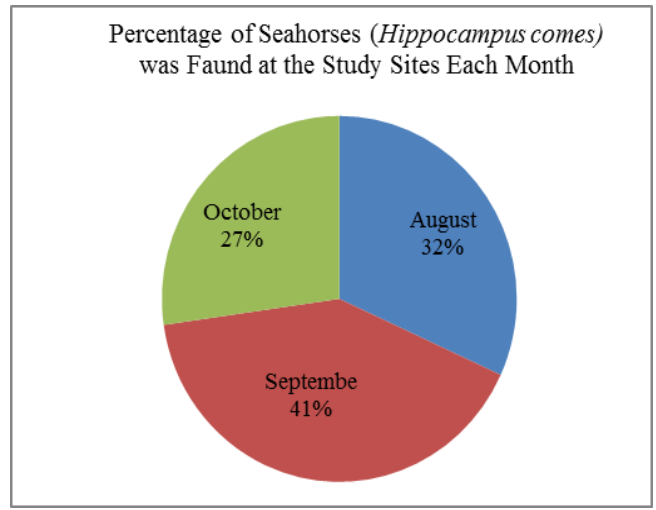

Fig. 2. Percentage of Number of Sea Horses Found in Sampling Locations Every Month.

The results of total seawall abundance analysis at the study sites can be seen in Fig 3 .

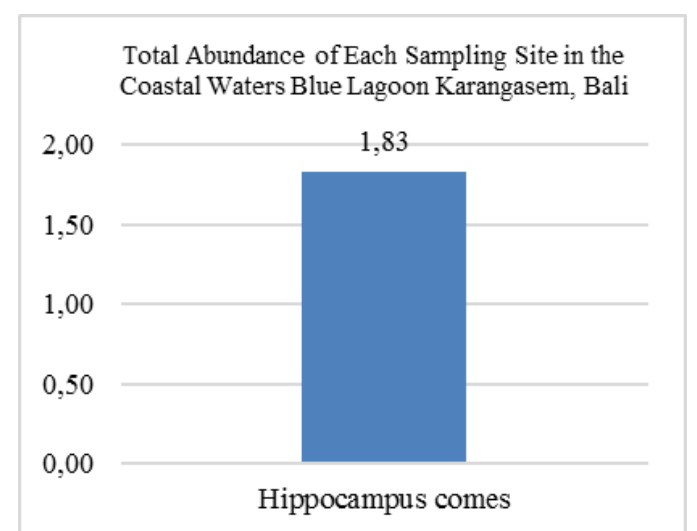

Fig. 3. Abundance of Total Kinds of Sea Horse at Sampling Location.

The result of total abundance analysis from all sampling sites in coastal waters was $1,83 \mathrm{ind} / \mathrm{m}^{2}$, where species of Hippocampus comes is a type of sea horse found in Blue Lagoon coastal waters Karangasem, Bali. The results of total seaweed density analysis at the study sites can be seen in Fig 4.

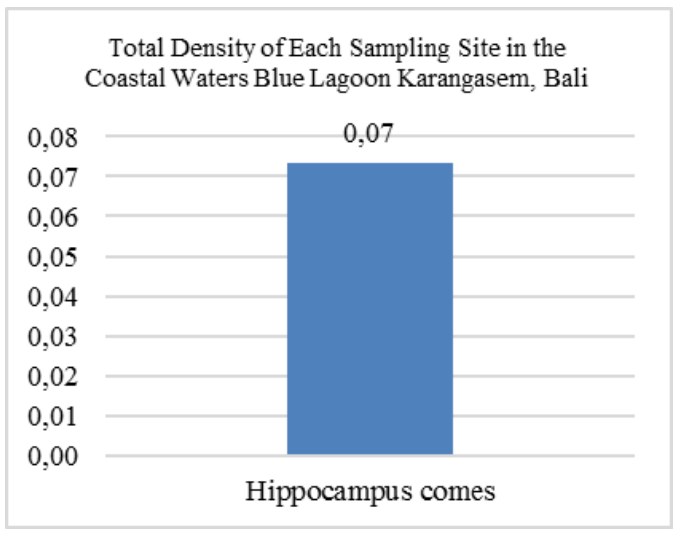

Fig. 3. Total Density of Sea Horses at Sampling Location. 
The total density analysis of all sampling sites in coastal waters was $0.07 \mathrm{ind} / \mathrm{m}^{2}$, where the highest species of Hippocampus comes to be the type of sea horse found in Blue Lagoon coastal waters Karangasem, Bali.. The Hippocampus comes alive in coral reef habitats and was found in waters with depths less than 20 meters.

The results of the measurement of chemical physics parameters in the waters of Blue Lagoon Beach Karangasem, Bali can be seen in Table 1.

TABLE I PHYSICS CHEMICAL PARAMETERS

\begin{tabular}{|c|c|c|c|c|}
\hline No & Parameter & $\begin{array}{l}\text { Range } \\
\text { Value }\end{array}$ & $\begin{array}{l}\text { Quality Standard } \\
\text { Kep.Men LH No. } \\
51 \text { Th.2004 [7] } \\
\text { About Sea Water } \\
\text { Quality Standards } \\
\text { For Marine Biota }\end{array}$ & Information \\
\hline 1. & $\begin{array}{l}\text { Tempera- } \\
\text { ture }\left({ }^{\circ} \mathrm{C}\right)\end{array}$ & $28-29$ & $28-30$ & $\begin{array}{c}\text { Natural and } \\
\text { allowed }<2{ }^{\circ} \mathrm{C} \\
\text { from normal } \\
\text { environmental } \\
\text { quality } \\
\text { conditions }\end{array}$ \\
\hline 2. & $\begin{array}{l}\text { Salinity } \\
\text { (ppt) }\end{array}$ & $27-29$ & $32-34$ & $\begin{array}{l}\text { Natural and } \\
\text { allowed }<5 \% \text { of } \\
\text { the seasonal } \\
\text { average }\end{array}$ \\
\hline 3. & DO (mg/l) & $7-7,75$ & $>5$ & $\begin{array}{c}>5 \text { of the } \\
\text { seasonal } \\
\text { average }\end{array}$ \\
\hline 4. & $\mathrm{pH}$ & $\begin{array}{c}7,08- \\
7,89\end{array}$ & $7-8,5$ & $7-8,5$ \\
\hline
\end{tabular}

\section{Discussion}

Population and Ecology of Sea Habitat Habitat in Blue Lagoon Coast Karangasem, Bali

The emergence of the species of Hippocampus comes in the Blue Lagoon area of Karangasem was quite worrying. This refers to the total density calculation results, while the total abundance is 0,0267 in August. It then shows an upward trend to 0,3 in September and declines back to 0,02 in October. The low abundance and densities of coral fish are thought to be due to the ability of these reef fish species to adapt and breed in environmental conditions in their habitats [3].

The condition of Blue Lagoon waters ecologically to date is still submitted in a good category for tourism but requires a more in-depth and comprehensive study as the basis for conservation policy formulation. The condition of coral reefs under the waters is very frequent disruption due to snorkeling path that leads to damaged conditions, it is based on the findings that the abundance of reef fish is very small with unobserved distribution well.

One of the real efforts that can be done by the stakeholders in conservation efforts was to build a snorkeling point at some point (point-point) to restrict tourists using the path along the coast so that it will reduce the damage that occurred. Besides, it is necessary to periodically monitor the area to maintain the stability of the function of the area as an environment-based tourism area.

Periodic monitoring can be conducted through a longterm research process by establishing zoning and permanent plots that are environmentally friendly so it is possible to make a long-term observation of the existence of Pipefish in the Blue Lagoon area of Karangasem through continuous comprehensive research.

The Effect of Aquatic Chemical Physics on Environmental Supporting Capacity

The results of the measurements performed in situ in Blue Lagoon Beach Waters show that the physical condition of aquatic chemistry is generally stable and suitable as a living habitat of Hippocampus comes in the waters of Blue Lagoon Karangasem Bali because based on water quality standards are still in good category and based on the tolerance range of aquatic organisms still within reasonable limits.

This is based on the ratio of chemical content in the waters with the quality standards established through Bali Governor Regulation No. 16 of 2016 [7]. This means that the Blue Lagoon Karangasem area is still very good as a natural habitat of Hippocampus comes. This research shows that the aquatic chemical physics condition still supports the sustainability of the area. But on the other hand, the environmental exploration of the tourism aspect that develops marine tourism in the form of snorkeling and diving in the Blue Lagoon region directly has the potential to damage and affect the stability of the water chemistry physics condition.

Therefore, the adjustment of the area conservation policy is needed to achieve the equilibrium between the development of the area as one of the areas of tourism that supports life and welfare, on the other hand still consider the sustainability of the region by making appropriate conservation efforts.

\section{CONCLUSION}

Ecological conditions include the distribution and abundance of reef fish Syngnathidae in the Blue Lagoon Coast of Karangasem Bali is considered worrying. The physical condition of the waters of Blue Lagoon Beach Karangasem Bali is still good for the habitat of the reef fish Syngnathidae.

The ecological conditions of the Blue Lagoon waters of Karangasem Bali can be used as supporting marine ecotourism that is developed by limiting the activity that may damage the corals as well as by providing special areas or pathways to enter the waters.

\section{ACKNOWLEDGMENT}

Thanks to Rector of Udayana University and Head of Institute for Research and Community Service Universities Udayana for the research funding. We also thanks to the research team for the assistance and support during the running of this research. 
Journal of Advances in Tropical Biodiversity and Environmental Sciences Vol. 2 No. 2, September 2018 (p-ISSN: 2549-6980)

\section{REFERENCES}

[1] Sale, P.F. 1991. The ecology on coral reef fishes. Academic Press, Inc. New York. xviii+754p.

[2] Hutomo, M. (1986). Community of Coral Fish and Visual Census Methods. LON LIPI. Jakarta.

[3] Krebs,C.J (1978) Ecology, the Experimental Analysis of Distribution and Abundance. Second Edition. Harper International Edition.

[4] Pauly D. (1984). Some Simple Methods for Assesment of Tropical Fiah Stock. FAO. Fisheries Technical
Paper No 234, Rome.

[5] Effendie, M.I. (2002). Fisheries Biology. Yayasan Pustaka Nusantara. Yogyakarta.

[6] Aziz K.A. (1989). Estimation of Tropical Fish Population Stock. Pusat Antar Universitas Ilmu Hayati - IPB Bogor.

[7] Decree of Director General of PHKA, Ministry of Environment and Forestry, Number of Decree. 51/IVSET/2015 on Quota on Natural Plant Taking and Wildlife Arrest for the Period of 2015. 